\title{
Trade Facilitation and Global Supply Chains : The Role of FTA Trade Facilitation Rules in Promoting Global Supply Chains
}

\author{
Hyo-young Lee*
}

\begin{abstract}
One of the important goals of trade facilitation is to lower the costs of trade that serve as a barrier to the developing countries from enjoying the benefits of increased trade and becoming integrated into global supply chains that account for nearly 60 percent of global trade today. The high trade costs that are plaguing most developing countries is mainly incurred from the lack of adequate trade-related infrastructure and low quality of institutions that hinder the efficient flow of goods across and within borders. Therefore, the trade facilitation rules that are contained in FTAs among bilateral trading partners are inevitably aimed at deepening their participation in the global value chain network. However, an observation of the FTAs concluded by Korea and the trade facilitation rules contained therein shows that the current trade facilitation rules in bilateral FTAs may be of little practical use for countries that lack the capacity to be involved in the international production activities in the first place. From the development perspective, the current WTO negotiations on trade facilitation which take full account of the special and differential treatment needs of the less developed country members appear more likely to contribute to providing the trading environment that is free from the barriers to trade that have inhibited the less developed countries from integration into the global supply chains and the benefits thereof.
\end{abstract}

Key Words : Trade Facilitation, Global Supply Chains, FTA, Logistics Performance, Aid for Trade

\footnotetext{
* Associate Research Fellow, Korea Institute for International Economic Policy (KIEP); Ph.D. in International Studies, Seoul National University. E-mail: hylee@kiep.go.kr. I am very grateful to the participants at the 2013 Seoul International Law Forum organized by the Korea Branch of the International Law Association, in particular Professors Nohyoung Park, Junha Kang, Daewon Kim, Guiguo Wang, and Laura Henry for their helpful comments on this paper. My special appreciation also goes to Professor Dukgeun Ahn for his insights and comments that provided the basis for this research.
} 


\section{INTRODUCTION}

\section{Why Trade Facilitation and Global Supply Chains?}

The importance of trade facilitation has risen significantly with the growth of global supply chains, in which goods cross borders multiple times, initially as inputs and ultimately as final products. Today, about 60 percent of global trade consists of trade in intermediate goods and services that are incorporated as production inputs and outputs in various stages of the global production process. In such a trading environment, the cost of trading across borders would serve as a barrier to the cross-border flow of exports and imports in global production networks. According to WTO estimates, such cost of trading amounts to some $\$ 2$ trillion, two thirds of which is a result of border and customs procedures. ${ }^{1)}$ Also, there are several empirical analysis results showing that the gains in global trade from smoother border procedures could be higher than the gains from tariff reduction. ${ }^{2)}$

With reduced tariff levels as a result of a series of multilateral trade negotiations under the auspices of the WTO, trade facilitation has been the subject of growing attention in international trade as a means to improve the 'quality' of trade environment for efficient trade operations. ${ }^{3)}$ Trade facilitation refers to the elimination of inefficiency caused by non-tariff barriers not only on the border, such as burdensome customs procedures, but, more broadly, also covers the behind-the-border regulations and trade-related infrastructure, the lack or inefficiency of which may hinder the flow of goods to the customer or final user. In order for a good to enter an import market, it not only has to go through customs and other administrative procedures that delay prompt clearance of goods, but the domestic logistics and communication infrastructure may also serve as a major barrier to the prompt delivery of goods to the intended destination even after crossing the border. Furthermore, various forms of domestic regulations, such as safety-related product standards or technical regulations may also inhibit the smooth entry of the imported goods into the domestic market.

1) UNCTAD, World Investment Report 2013, Global Value Chains: Investment and Trade for Development, 182

2) According to Bagai, Newfarmer and Wilson (2004), transport costs are important relative to other trade barriers. For 168 out 215 U.S. trading partners, transport cost barriers clearly outweighed tariff barriers. Anderson and van Wincoop (2004) also estimated that in high-income countries, trade costs amount on average to a $170 \%$ ad valorem barrier to trade, while tariffs and non-tariff barriers accounted for less than $20 \%$ of on-the-border trade costs.

3) A. Grainger (2011), 'Trade Facilitation: A Conceptual Review', Journal of World Trade 45(1), 40. 
On the other hand, the growth of global supply chains has also encouraged the establishment of 'deep' bilateral trade agreements that go beyond tariff reduction. The increased amount of trade in parts and components as part of the international production network is shown to be closely associated with the greater depth of newly signed agreements among FTA members. In fact, several empirical analysis have shown that the greater the depth of an agreement, the larger the increase in trade among FTA members. ${ }^{4}$ ) Therefore, it seems that countries that are already involved in global supply chains are more willing to sign preferential trade agreements with their partners in order to secure their trading relationships as providers of intermediate goods and services. As a result, it would be only natural that such FTAs to secure the trading environment for global supply chains provide rules for facilitating trade through simplified import and export procedures at the border, in addition to many other trade and investment liberalizing measures, for the members to engage more freely in international production activities.

\section{Trade Facilitation Rules for Promoting Global Supply Chains}

The trade facilitation rules that are needed to promote active participation in global supply chains have been identified in several previous research. According to a recent report by UNCTAD (2013) on global supply chains, the key location-specific policy determinants for a country to become engaged in global supply chain activities are quite broad, ranging from customs and border procedures to investment policy and intellectual property regimes. The trading environment for promoting integration into global supply chains, in fact, may not be much different from the general environment for promoting global trade, since essentially, trade costs would have to be lowered. However, in addition to the reduction of tariff levels and border procedures, the promotion of global supply chains requires a solid transportation or logistics infrastructure that would enable the smooth flow of the input and output goods between the local production sites and transportation sites (i.e. ports, airports, railway). The improvement in such logistics performance has been empirically shown to have the greatest positive effects in expanding trade for developing countries. ${ }^{5}$ )

In particular, one of the problems the developing countries are facing that inhibit their integration into the international production network is the lack of adequate infrastructure

4) WTO, World Trade Report 2011, The WTO and Preferential Trade Agreements: From Co-existence to Coherence, 145.

5) Hoekman and Nicita (2008), Wilson et. al $(2003,2005)$. For more on the economic impact of trade facilitation, refer to, for example, OECD Trade Policy Working Paper No. 21 (TD/TC/WP(2005) 12/FINAL), 12 Oct. 2005. 
for trade logistics (transportation and telecommunication), which is an essential element for the movement of goods in a rapid, reliant, and less costly manner. In fact, while reducing tariff and non-tariff barriers may be important requirements for trade promotion in general, the trade-related infrastructure may indeed be an essential and basic element for the less developed economies. Even for the faster developing countries among the less developed economies, improved efficiency in trade logistics inevitably leads to enhanced performance in the global supply chain network. $\left.{ }^{6}\right)$

Furthermore, the negotiations in the WTO which are discussing reforms to the traditional rules on trade facilitation contained in GATT Article $V$ (freedom of transit), Article VII (fees and formalities connected with importation and exportation), and Article $X$ (publication and administration of trade regulations) calls for attention to issues related to the transportation and logistics related infrastructure for the flow of goods across and within borders.7) More importantly, the Doha Ministerial Declaration (WTO 2001) refers to trade facilitation as "expediting the movement, release and clearance of goods, including goods in transit". This leaves more room for defining trade facilitation more broadly, to focus more attention on the level of physical infrastructure for facilitating trade within the border as well.

Based on the above discussion, it can be observed that trade facilitation is a broad concept that not only includes customs procedures at the border, but also the trade-related infrastructure, such as logistics capability for the transportation of goods at both across and within borders, and the physical infrastructure such as roads, ports, and information and telecommunication networks. Furthermore, when taking into account the importance of trade facilitation for the promotion of global supply chains, trade facilitation also refers to the level of trade and investment related policy regulations that create and maintain a conducive environment for active participation in global supply chains.

Table 1 below shows a break-down of trade facilitation measures based on previous research to be used as a framework for analysis for examining the current rules on trade facilitation and identifying any problems should they exist. In broader terms, trade facilitation can be distinguished into 'border' trade facilitation (TF) measures and 'inside-the-border' TF measures on one axis, and into 'hard' (more physical) and 'soft' (more regulatory) TF measures on the other axis. While customs procedures and other administrative red tape can be classified as 'soft' and 'border' trade facilitation measures,

6) In fact, several economic analyses have shown that the impact of improved trade facilitation leads to increased trade performance. For example, refer to: Wilson et. al (2003, 2005), Wilson and Otsuki (2007).

7) Most recently, the negotiations of the Doha Development Agenda have culminated in the final text on the Agreement on Trade Facilitation, which was adopted as part of the Ministerial Declaration at the Ninth Session of the WTO Ministerial Conference in Bali. WT/MIN(13)/W/1/Rev.1, 7 December 2013. 
the domestic regulations that affect the inflow of foreign exports and investment can be categorized as 'soft' and 'inside-the-border' trade facilitation measures. The physical infrastructure for trade operations, such as road and port facilities, and other logistics capability for enabling the smooth flow of goods after goods cross the national border can be classified as 'hard' and 'inside-the-border' trade facilitation measures. Port reform and modernization efforts using IT technology can be categorized as 'hard' and 'border' TF measures.

\section{Table 1.}

Categorization of Trade Facilitation Measures

\begin{tabular}{c|c:c}
\hline & Border TF measures & Inside-the-border TF measures \\
\hline Hard TF measures & Port reform and modernization & $\begin{array}{c}\text { Trade-related infrastructure } \\
\text { Logistics capability }\end{array}$ \\
Soft TF measures & $\begin{array}{c}\text { Customs and administrative } \\
\text { procedures }\end{array}$ & $\begin{array}{c}\text { Domestic regulatory } \\
\text { environment }\end{array}$ \\
\hline
\end{tabular}

In the following section, the rules on trade facilitation developed under the WTO framework through the Doha negotiations will be examined, and compared with the trade facilitation rules contained in FTAs. Based on this analysis, this paper observes several issues regarding the practical usefulness of bilateral trade facilitation rules, especially for the developing countries which are in most need of improved trade facilitation measures in order to become more integrated into global supply chains.

\section{WTO Rules on Trade Facilitation}

Trade facilitation was formally raised as one of the four agenda items for multilateral discussions at the 1996 ministerial conference in Singapore.8) The ministers instructed the WTO Council for Trade in Goods to start exploratory and analytical work on the "simplification of trade procedures in order to assess the scope for WTO rules in this area "9) The subsequent Doha Ministerial Declaration adopted in 2001 reaffirmed the mandate for negotiations on trade facilitation, recognizing the case for "further expediting the

8) The three other "Singapore issues" that were subsequently dropped from the WTO negotiation agenda were: transparency in government procurement, trade and investment, and competition policy.

9) Singapore Ministerial Declaration, WT/MIN(96)/DEC, 18 December 1996. 
movement, release and clearance of goods, including goods in transit, and the need for enhanced technical assistance and capacity building in this area", and to "clarify and improve relevant aspects of Articles V, VIII and X of the GATT 1994" and also to "identify the trade facilitation needs and priorities of members, in particular developing and least-developed countries".10)

In August 2004, negotiations on trade facilitation were formally launched with the Declaration adopted by the General Council (so-called "July 2004 package"), on the basis of modalities that were contained in Annex D of the General Council Decision. ${ }^{11}$ ) In accordance with the modalities, the purpose of negotiations on trade facilitation were to "clarify and improve the relevant aspects of Articles V, VIII and X of GATT 1994 with a view to further expediting the movement, release and clearance of goods, including goods in transit", and aimed at "enhancing technical assistance and support for capacity building in this area". Furthermore, the results of the negotiations were to take full account of "the principle of special and differential treatment for developing and least-developed countries", and as an integral part of negotiations, seek to "identify their trade facilitation needs and priorities, particularly those of developing and least-developed countries, and shall also address the concerns of developing and least-developed countries related to cost implications of proposed measures".12) Based on the mandate for negotiations, the Negotiating Group on Trade Facilitation (NGTF) was established by the Trade Negotiations Committee in October 2004, soon after which the Negotiating Group agreed on a Work Plan and a schedule of meetings at its first meeting. The momentum for the negotiations on trade facilitation was reaffirmed in the Hong Kong Ministerial Declaration adopted in December 2005, in which the Negotiating Group provided a report on its work done so fa r. 13)

The Doha negotiations on trade facilitation, in accordance with its mandate, centered on the revisions to the trade facilitation related provisions in GATT: Article V (freedom of transit), Article VIII (fees and formalities connected with importation and exportation), and Article X (publication and administration of trade regulations). ${ }^{14)}$ Based on the Negotiating

10) Doha Ministerial Declaration, WT/MIN(01)/DEC/1, 20 November 2001, Item 27.

11) Doha Work Programme, Decision Adopted by the General Council on 1 August 2004, WT/L/579, 2 August 2004.

12) Annex D, Modalities for Negotiations on Trade Facilitation, annexed to the Doha Work Programme, WT/L/579 (2 Aug. 2004), paras. 1-5.

13) Annex E: Trade Facilitation, Report by the Negotiating Group on Trade Facilitation to the TNC, in the Hong Kong Ministerial Declaration, WT/MIN(05)/DEC, 22 December 2005.

14) GATT Article V (freedom of transit) provides the rules for creating an environment where the transit of goods is free from transport barriers and discrimination between suppliers or firms from foreign countries; Article VIII (fees and formalities connected with importation and exportation) relates in general to customs clearance procedures and administrative barriers or transparency issues in fees and 
Group's Work Plan,15) Members contributed to the agreed agenda, and revisions to the GATT provisions were mainly based on the submitted proposals by Member countries. ${ }^{16)}$ As a result of years of negotiations and drafting based on the proposals, the Negotiating Group has been working on the Draft Consolidated Negotiating Text for WTO rules on trade facilitation as a basis for negotiations on the trade facilitation text.17) Most recently, at the $9^{\text {th }}$ Ministerial Conference in Bali, the trade ministers were finally able to agree on a binding trade facilitation text ${ }^{18)}$ which is expected to enter into force within approximately two years. ${ }^{19)}$ Table 2 below lists the main provisions that are contained in the current final version of the agreement:

Table 2.

Agreement on Trade Facilitation (as of December 2013)

\begin{tabular}{|c|c|}
\hline & Provisions in the WTO Agreement on Trade Facilitation \\
\hline \multirow{9}{*}{ Section I } & Article 1: Publication and Availability of Information \\
\hline & $\begin{array}{l}\text { Article 2: Opportunity to Comment, Information before Entry into Force and } \\
\text { Consultation }\end{array}$ \\
\hline & Article 3: Advance Rulings \\
\hline & Article 4: Appeal or Review Procedures \\
\hline & $\begin{array}{l}\text { Article 5: Other Measures to Enhance Impartiality, Non-discrimination and } \\
\text { Transparency }\end{array}$ \\
\hline & $\begin{array}{l}\text { Article 6: Disciplines on Fees and Charges Imposed on or in Connection with } \\
\text { Importation or Exportation }\end{array}$ \\
\hline & Article 7: Release and Clearance of Goods \\
\hline & Article 8: Expedited Shipments \\
\hline & Article 9: Border Agency Cooperation \\
\hline
\end{tabular}

rules applied to goods crossing borders; Article X (publication and administration of trade regulations) contains rules to ensure timely publication of regulations regarding imports, including fees, customs valuation procedures, etc.

15) Negotiating Group and Trade Facilitation, Work Plan and Schedule of Meetings, TN/TF/1, 16 November 2004.

16) For an overview of the proposals submitted by Member countries, refer to WTO Negotiations on Trade Facilitation: Compilation of Members' Textual Proposals, TN/TF/W/43/Rev.19, 30 June 2009.

17) Draft Consolidated Negotiated Text - Revision, Negotiating Group on Trade Facilitation, TN/TF/W/165/ Rev.18, 23 October 2013.

18) Agreement on Trade Facilitation, Annex of the Draft Ministerial Decision on the Agreement on Trade Facilitation, WT/MIN(13)/W/8, 6 December 2013.

19) 'U.S. Gets Binding Trade Facilitation Deal, Implementation to Last Several Years', Inside U.S. Trade (World Trade Online), 7 December 2013. 


\begin{tabular}{|c|c|}
\hline & Provisions in the WTO Agreement on Trade Facilitation \\
\hline & Article 10: Formalities Connected with Importation, Exportation and Transit \\
\hline & Article 11: Freedom of Transit \\
\hline & Article 12: Customs Cooperation \\
\hline & Article 13: Institutional Arrangements \\
\hline \multirow{12}{*}{ Section II } & $\begin{array}{l}\text { Special and Differential Treatment Provisions for Developing Country Members } \\
\text { and Least Developed Country Members }\end{array}$ \\
\hline & 1. General Principles \\
\hline & 2. Categories of Provisions \\
\hline & 3. Notification and Implementation of Category A \\
\hline & $\begin{array}{l}\text { 4. Notification of Definitive Dates for Implementation of Category B and } \\
\text { Category C }\end{array}$ \\
\hline & $\begin{array}{l}\text { 5. Early Warning Mechanism: Extension of Implementation Dates for Provisions } \\
\text { in Categories B and C }\end{array}$ \\
\hline & 6. Implementation of Category B and Category C \\
\hline & 7. Shifting between Categories B and C \\
\hline & $\begin{array}{l}\text { 8. Grace Period for the Application of the Understanding on Rules and } \\
\text { Procedures Governing the Settlement of Disputes }\end{array}$ \\
\hline & 9. Provision of Assistance for Capacity Building \\
\hline & 10. Information on Assistance to be Submitted to the Committee \\
\hline & Final Provisions \\
\hline
\end{tabular}

The Negotiating Group on Trade Facilitation has come far in negotiating the provisions on customs administration as well as the elements regarding special and differential treatment for developing and least developed countries. While there have been disagreements over several provisions in the Agreement, reflecting the different interests of some of the developed and developing country Members, ${ }^{20)}$ in the end, the Members have been able to come up with a final agreement that shows significant development in the incorporation of provisions for the special and differential treatment for developing and least developed Member countries. In particular, the distinction of three different categories

20) These include provisions on the expedited release for goods entered through air cargo facilities (Article 8.1, Section I), which was pushed by the U.S. negotiators representing the interests of its express delivery companies. Article 6 in Section I is also a result of compromised language between the EU and Panama on the issue of customs brokers. While the EU had sought language banning WTO members from requiring the use of customs brokers, Panama insisted on including the language, as it currently has such a requirement as do several other Latin American countries. 
of commitments (Categories $\mathrm{A}, \mathrm{B}$, and $\mathrm{C}$ ) with different periods of transition for implementing the commitments is quite notable. ${ }^{21)}$ These provisions have apparently taken full account of the implementation related concerns of the developing country Members that the obligations arising out of negotiations would be expensive and difficult to administer. Some countries even feared that additional rules might involve institutional changes that would exceed their implementation capacities, and thus increase the likelihood of becoming subject to dispute settlement action for failure to follow the new WTO obligations. ${ }^{22)}$

The provision of technical or financial assistance for capacity building by developed countries and relevant international organizations, although somewhat toned down in the final text, has been explicitly recognized as a means to assist the developing and least-developed country members to implement the provisions of the agreement. ${ }^{23)}$ The donor countries will agree to engage in such assistance programs on mutually agreed terms, either bilaterally or through appropriate international organizations, such as the IMF, OECD, UNCTAD, WCO and the World Bank. Furthermore, in various provisions in Section II, it provides that the developing and least-developed country Members will not be held accountable for any lack of implementation of its obligations even after the provision of assistance by donor countries as long as they follow the due procedures for notifying its inability for implementation. There is also emphasis on the "sustainability" of the assistance programs, requiring the programs to take account of the development framework and priorities of the recipient countries and to promote coordination with other Members and relevant institutions to ensure maximum effectiveness of the assistance.

In conclusion, the WTO rules on trade facilitation as incorporated in the new trade facilitation agreement have developed an elaborate set of rules on trade facilitation, that provide detailed rules particularly with regard to customs and administrative procedures and other non-tariff barriers that are applied at the border (soft/border TF measures). Port reform and modernization (hard/border TF measures) will also be realized as a result of the implementation of obligations, especially with regard to the provisions on expedited shipments under Article 7 (release and clearance of goods). The section on special and differential treatment for developing and least developed countries apparently provide the legal basis for the provision of technical assistance and capacity building, which may include assistance in building the trade-related infrastructure and logistics capability for

21) Agreement on Trade Facilitation, above note 18, Section II, Articles 2 through 8.

22) Bagai, Newfarmer and Wilson (2004), above note 2.

23) Previously, in the most recent draft negotiating text, it was explicitly recognized as a "precondition for the acquisition of implementation capacity by developing country and least developed country Members in respect of provisions requiring assistance". Draft Consolidated Negotiating Text, above note 17, Section II, Article 8.1. 
transporting goods within the border (hard/inside-the-border TF measures). On the other hand, the TF measures pertaining to the domestic regulatory environment is a broader area which cannot be covered by the rules on trade facilitation alone.

\section{Trade Facilitation Rules in the Real World : FTA Rules on Trade Facilitation}

This section examines the trade facilitation-related chapters in the FTA texts concluded by Korea so far. Beginning with the Korea-Chile FTA that entered into force in April 2004, Korea has nine FTAs that are effective and one most recently signed FTA with Columbia that has yet to go into force. The following table lists the FTAs that have been concluded by Korea to date and some of the features of the provisions on trade facilitation in each FTA.

\section{Table 3.}

Korean FTAs and Bilateral Trade Facilitation Rules

\begin{tabular}{|c|c|c|l|}
\hline Korean FTA & Status & $\begin{array}{c}\text { Rules on } \\
\text { Trade Facilitation }\end{array}$ & \multicolumn{1}{c|}{ Features } \\
\hline Korea-Chile & $\begin{array}{c}\text { Effective } \\
\text { (Apl. 2004) }\end{array}$ & $\begin{array}{c}\text { Chapter 5 } \\
\text { (Customs Procedures) }\end{array}$ & $\begin{array}{l}\text { - No specific provision on trade } \\
\text { facilitation (TF) } \\
\text { - Mainly covering certification \& } \\
\text { verification of origin } \\
\text { - Provision on "cooperation", mainly } \\
\text { regarding collection \& exchange of } \\
\text { export/import information, } \\
\text { transmission of customs documents }\end{array}$ \\
\hline Korea-Singapore & Effective & $\begin{array}{c}\text { Chapter 5 } \\
\text { (Mar. 2006) }\end{array}$ & $\begin{array}{l}\text { (Customs Procedures) } \\
\text { - Mainly provisions on certification of } \\
\text { origin, advance ruling, temporary } \\
\text { admission of goods in transit } \\
\text { - Requirement of customs cooperation } \\
\text { on paperless customs clearance, } \\
\text { sharing of best practices \& } \\
\text { information }\end{array}$ \\
\hline Korea-EFTA & Effective & Annex 1 & $\begin{array}{l}\text { - Divided sections on 'proof of origin', } \\
\text { 'arrangements for administrative } \\
\text { cooperation, and 'customs }\end{array}$ \\
\hline
\end{tabular}




\begin{tabular}{|c|c|c|c|}
\hline Korean FTA & Status & $\begin{array}{c}\text { Rules on } \\
\text { Trade Facilitation }\end{array}$ & Features \\
\hline & & & $\begin{array}{l}\text { cooperation' } \\
\text { - Requirement of customs cooperation } \\
\text { on harmonization \& simplification of } \\
\text { customs procedures, sharing of best } \\
\text { practices on customs control, } \\
\text { exchange of expertise, and joint } \\
\text { training }\end{array}$ \\
\hline Korea-ASEAN & $\begin{array}{c}\text { Effective } \\
\text { (May. 2009) }\end{array}$ & $\begin{array}{c}\text { Annex } 3 \\
\text { (Rules of Origin) } \\
\text { Appendix } 1 \\
\text { (Operational } \\
\text { Certification } \\
\text { Procedures for Rules } \\
\text { of Origin) }\end{array}$ & $\begin{array}{l}\text { - No specific provisions on trade } \\
\text { facilitation } \\
\text { - Mainly provisions on certification } \\
\text { procedures for rules or origin and } \\
\text { other customs related administrative } \\
\text { matters }\end{array}$ \\
\hline $\begin{array}{l}\text { Korea-India } \\
\text { (CEPA) }\end{array}$ & $\begin{array}{c}\text { Effective } \\
\text { (Jan. 2010) }\end{array}$ & $\begin{array}{c}\text { Chapter } 5 \\
\text { (Trade Facilitation } \\
\text { and Customs } \\
\text { Cooperation) }\end{array}$ & $\begin{array}{l}\text { - First official use of language 'trade } \\
\text { facilitation' } \\
\text { - Provisions on 'automation' (“each } \\
\text { party shall endeavour to use } \\
\text { information technology that expedites } \\
\text { procedures for the release of goods"), } \\
\text { and establishment of a 'customs } \\
\text { committee' (to address issues related } \\
\text { to interpretation and application of } \\
\text { rules, review rules of origin, and } \\
\text { develop guidelines for } \\
\text { customs-related matters) } \\
\text { - Requirement of customs cooperation } \\
\text { on adopting international best } \\
\text { practices for trade facilitation } \\
\text { (“adoption of advanced customs } \\
\text { procedures") }\end{array}$ \\
\hline Korea-EU & $\begin{array}{l}\text { Effective } \\
\text { (Jul. 2011) }\end{array}$ & $\begin{array}{c}\text { Chapter } 6 \\
\text { (Customs and } \\
\text { Trade Facilitation) }\end{array}$ & $\begin{array}{l}\text { - Specific mentioning that objectives of } \\
\text { customs cooperation include } \\
\text { "working together to reinforce the } \\
\text { customs related aspects for securing } \\
\text { the logistics chain of international } \\
\text { trade" } \\
\text { - Establishment of a 'customs } \\
\text { committee' to "resolve any } \\
\text { differences that arise between the }\end{array}$ \\
\hline
\end{tabular}




\begin{tabular}{|c|c|c|c|}
\hline Korean FTA & Status & $\begin{array}{c}\text { Rules on } \\
\text { Trade Facilitation }\end{array}$ & Features \\
\hline & & & $\begin{array}{l}\text { Parties" regarding trade facilitation } \\
\text { and mutual administrative assistance } \\
\text { in customs matters }\end{array}$ \\
\hline Korea-Peru & $\begin{array}{c}\text { Effective } \\
\text { (Aug. 2011) }\end{array}$ & $\begin{array}{c}\text { Chapter } 5 \\
\text { (Customs } \\
\text { Administration and } \\
\text { Trade Facilitation) }\end{array}$ & $\begin{array}{l}\text { - Separate sections on "facilitation" and } \\
\text { "customs cooperation" } \\
\text { - More detailed procedures on customs } \\
\text { cooperation (mutual administrative } \\
\text { assistance on customs matters, request } \\
\text { \& execution of assistance, assistance } \\
\text { expenses, etc.) } \\
\text { - Establishment of a "committee on } \\
\text { customs, origin, and trade facilitation" } \\
\text { with mandate to "settle any disputes } \\
\text { related to interpretation, application, } \\
\text { and administration of this Chapter" } \\
\text { and to "work on the development of } \\
\text { an electronic certification and } \\
\text { verification system" }\end{array}$ \\
\hline Korea-US & $\begin{array}{c}\text { Effective } \\
\text { (Mar. 2012) }\end{array}$ & $\begin{array}{c}\text { Chapter } 7 \\
\text { (Customs } \\
\text { Administration and } \\
\text { Trade Facilitation) }\end{array}$ & $\begin{array}{l}\text { - Rather simple rules covering } \\
\text { publication, release of goods, } \\
\text { automation, risk management, } \\
\text { confidentiality, express shipments, } \\
\text { advance rulings and cooperation } \\
\text { - Provision on 'penalties', allowing for } \\
\text { use of civil or administrative } \\
\text { penalties, and criminal sanctions for } \\
\text { violations of customs law } \\
\text { - Customs cooperation on providing } \\
\text { "technical advice and assistance for } \\
\text { facilitating the implementation of } \\
\text { international supply chain standards" }\end{array}$ \\
\hline Korea-Turkey & $\begin{array}{c}\text { Effective } \\
\text { (Nov. 2012) }\end{array}$ & $\begin{array}{c}\text { Chapter } 3 \\
\text { (Customs and } \\
\text { Trade Facilitation) }\end{array}$ & $\begin{array}{l}\text { - Similar TF rules as with KOR-EU } \\
\text { FTA } \\
\text { - Specific mentioning of "technical } \\
\text { cooperation" as being "fundamental to } \\
\text { facilitating compliance with the } \\
\text { obligations set forth'· and to achieve } \\
\text { high levels of trade facilitation", and } \\
\text { agreement on development of a }\end{array}$ \\
\hline
\end{tabular}




\begin{tabular}{|c|c|c|c|}
\hline Korean FTA & Status & $\begin{array}{l}\text { Rules on } \\
\text { Trade Facilitation }\end{array}$ & Features \\
\hline & & & $\begin{array}{l}\text { "technical cooperation program under } \\
\text { mutually agreed terms as to the scope, } \\
\text { timing and cost of cooperative } \\
\text { measures in customs" } \\
\text { - Establishment of a customs } \\
\text { committee for bilateral dispute } \\
\text { resolution }\end{array}$ \\
\hline Korea-Columbia & $\begin{array}{c}\text { Signed } \\
\text { (Feb. 2013) }\end{array}$ & $\begin{array}{c}\text { Chapter } 4 \\
\text { (Customs } \\
\text { Administration and } \\
\text { Trade Facilitation) }\end{array}$ & $\begin{array}{l}\text { - Separate sections on 'trade } \\
\text { facilitation' and 'customs cooperation } \\
\text { and mutual assistance' } \\
\text { - Detailed provisions on customs } \\
\text { cooperation similar to KOR-PERU } \\
\text { FTA } \\
\text { - Explicit mentioning of bilateral } \\
\text { cooperation to ensure that 'training } \\
\text { and technical assistance programs' are } \\
\text { jointly organized for "providing } \\
\text { expertise and capacity building on } \\
\text { legislative and technical matters to } \\
\text { develop and enforce customs } \\
\text { legislation, and application of modern } \\
\text { customs techniques". }\end{array}$ \\
\hline
\end{tabular}

Almost all the Korean FTAs contained chapters that exclusively cover customs administration or procedures, although some of the early Korean FTAs did not contain specific provisions on trade facilitation. Rather, they were focused on providing detailed rules for operation of the certification and verification procedures for rules of origin and other administrative matters related to customs.

On the other hand, the latter FTAs concluded by Korea contained chapters which explicitly used the language 'trade facilitation', in addition to 'customs', 'customs administration' or 'customs procedures' in the title and text of the chapters. With the introduction of trade facilitation, provisions on 'automation' or the 'use of automated systems' for expediting procedures for customs clearance were included in the subsequent FTA texts. Furthermore, several of these latter FTAs contained divided sections that separately covered matters on trade facilitation and customs cooperation. This appears to imply that there is recognition that the measures for trade facilitation and the requirements for bilateral cooperation on customs matters need be separately addressed, especially in the case of FTAs signed with less developed country partners. 
The provisions on customs cooperation appear to have been dealt rather more importantly in the Korean FTAs concluded with India, Peru, Turkey and Columbia (developing country partners). First of all, the procedures for cooperation were dealt with more elaborately in a separate section, with detailed provisions on mutual administrative assistance in customs matters, form and substance of requests for assistance, execution of assistance requests, exceptions to obligation to provide assistance, assistance expenses, consultation, and establishment of a customs committee. Furthermore, the two most recently concluded FTAs with Turkey and Columbia explicitly refers to the importance of technical cooperation as a fundamental element in achieving higher levels of trade facilitation, providing for the development of technical cooperation programs ${ }^{24}$ ) and providing expertise and capacity building on legislative and technical matters related to customs matters. 25 )

FTAs established with EU and US (developed country partners) notably contained provisions that explicitly recognized the relevance of trade facilitation measures for securing their positions in global supply chains. ${ }^{26)}$ On the other hand, the chapters on trade facilitation in these FTAs did not contain elaborate provisions on customs cooperation, and were rather simple and more 'practical' in terms of coverage for governing the rules on customs administration. On the other hand, there was a 'penalties' provision in the Korea-US FTA, which allowed for the imposition of civil or administrative penalties, and even criminal sanctions in case of violations of respective customs laws. ${ }^{27)}$ The customs committee that is provided for establishment in both FTAs was provided with the mandate to resolve disputes should issues related to customs matters arise.

On the whole, there appears to be an evident evolution in the rules on trade facilitation in the Korean FTAs as observed so far. The chapters dealing with this subject matter seem to contain provisions that became more explicit and elaborate in providing the rules for facilitating trade through customs administration and cooperation. More importantly, FTAs concluded with developing partner countries were explicitly in recognition of the importance of technical assistance and capacity building for implementing the rules on trade facilitation. This was in stark contrast to the FTAs that Korea agreed with the developed partner countries, which were not as elaborate in the area of customs cooperation.

However, it should also be noted that in the former category of the Korean FTAs, the technical cooperation programs were seemingly limited to cooperative measures in only

\footnotetext{
24) Korea-Turkey FTA, Article 3.14.5

25) Korea-Columbia FTA, Article 4.11.2 (b)

26) Korea-US FTA, Article 7.5.8; Korea-EU FTA, Article 6.13.4 (h).

27) Korea-US FTA, Article 7.9.
} 
customs and customs-related areas, which are to be agreed on mutually agreed terms regarding the scope, timing and cost of the cooperative measures involved, or to be provided in the form of "mutual assistance". Therefore, the technical cooperation would not necessarily cover the building of trade-related infrastructure such as for transportation or telecommunications, which would be the more fundamental elements for trade facilitation for less developed country members that are not fully integrated into the international trading system. Furthermore, there are also provisions that allowed for exceptions to the obligation to provide assistance, as in the case of Korea-Peru FTA, under which parties may refuse to give assistance when it is against their interest, ${ }^{28}$ ) and waive any claims for expenses incurred for the provision of assistance. ${ }^{29)}$ Such provisions on exceptions and assistance expenses are also present in the Korea-Columbia FTA. ${ }^{30}$ )

It seems to be the case that while the trade facilitation rules contained in FTAs do recognize the importance of the implementation concerns of the developing and less developed Member countries and has incorporated provisions to emphasize cooperative efforts in this area through technical assistance and capacity building, the real substance of the assistance to be provided is not clearly defined and limited in scope in order to have practical usefulness for the less developed Member countries.

\section{Issues and Implications}

The multilateral rules on trade facilitation that have been negotiated by the WTO Members are centered on revisions to the traditional GATT provisions on customs clearance and administrative barriers, in addition to the renewed emphasis on the implementation concerns of the developing and least developed country Members of the WTO. However, in practice, the FTAs that are established among trading partners for the promotion of bilateral trade and further integration into global supply chain networks seem to contain rules on trade facilitation that are more focused on deepening the already established trade relationship, but limited in scope regarding the provision of assistance that

28) Article 5.18 of the Korea-Peru FTA stipulates that: "The Parties may refuse to give assistance as provided for in this Chapter, where such assistance would: (a) be likely to prejudice their sovereignty, public policy, security, or other essential interests; (b) involve currency or tax regulations other than customs legislation; or (c) violate an industrial, commercial, or professional secret."

29) Article 5.22 of the Korea-Peru FTA: "The Parties shall waive all claims on each other for the reimbursement of expenses incurred in accordance with this Chapter, except, as appropriate, for expenses related to experts and witnesses and to interpreters and translators who are not public officials."

30) Articles 4.15 and 4.18, Korea-Columbia FTA. 
would match the needs of the less developed country partners. ${ }^{31)}$ As observed previously, the provisions on customs cooperation are practically limited by requiring the assistance programs to be "mutual" (rather than being 'unilateral', which would be the typical nature of any provision of assistance on technical matters), whatever that substantially means.

However, in fact, such lack of depth or specific commitments to provide technical assistance, including the costs for assistance, in the bilateral FTA texts is understandable, since any unilateral provision of assistance would involve the 'free-riding' problem, under which the benefits from the establishment of the physical infrastructure to facilitate trade would be enjoyed by the rest of the trading community without paying any cost. Indeed, a multilateral approach may be more appropriate for implementing technical assistance programs involving physical investment and funding, when considering the externalities that are involved in such activities. Indeed, it would not be a strategic choice for the bilateral donor country if the benefits of the unilateral trade-related costs would be freely enjoyed by its competing trading partners. Furthermore, incorporating any bilateral commitments on the provision of trade development assistance in FTAs may need a precautionary approach, since the commitments made may become subject to disputes under WTO or FTA dispute settlement mechanisms for lack of implementation of the FTA obligations. Due to such structural problems, the trade facilitation provisions in FTAs may inherently have to be limited to promising only cooperation through the sharing of best practices and training at best.

Perhaps for these reasons, the current trade facilitation rules in the FTAs (at least those established by Korea with its trading partners) seem to be focused on further improving the environment for countries that are already engaged in the global supply chain network. Through commitments to further reduce the customs and administrative barriers that their traders are facing, parties to the bilateral agreements are likely to expect better performance in global supply chain activities. Also, among the developing countries, those that are equipped with the essential trade-related infrastructure, but are hindered by the inefficiency in their domestic regulations particularly in the customs area would also gain from the current trade facilitation rules contained in the FTAs.

However, such an observation leads to the conclusion that the developing and least developed countries that still lack the adequate physical environment for trading would still not be able to benefit from current FTA rules with regards to trade facilitation. Since the trade facilitation rules in FTAs do not include provisions on the 'hard' and

31) The main barriers for implementation of the proposed trade facilitation measures faced by developed and least-developed countries were: lack of cooperation/coordination; human resources constraints; legislation and policy-related issues; institutional-related issues; and poor trade-related infrastructure. Negotiating Group on Trade Facilitation, Summary of WTO Trade Facilitation Needs Assessment Results, TN/TF/W/177, 21 May 2012. 
'inside-the-border' trade facilitation measures, of which the least developed countries are in most need of, the impact of FTAs for connecting the less developed countries to international production chains through improved trade facilitation measures may be quite disappointing. In other words, the role of FTA trade facilitation rules in integrating the developing and least developed country Members into the global supply chain network appear to be quite limited, and the current FTA trade facilitation rules may be of little practical use for countries that lack the capacity to be involved in the international production activities in the first place.

As a consequence, the efforts for improved trade facilitation for the less developed Members of the WTO may inevitably have to rely on the multilateral negotiations that are being conducted under the auspices of the WTO. In this sense, the Aid for Trade initiative which is currently being led by the WTO gains more significance, and all the more so, as the recently concluded Global Review of Aid for Trade was conducted under the theme of "Connecting to Value Chains", with focus on how to use development assistance to developing and least developed country firms to engage in value chains. Quite opportunely, the aim of the high-level meeting was to examine strategies to connect developing and least developed country firms to international value chains, and to discuss how they could best derive benefits from the development efforts. ${ }^{32)}$ Such efforts, combined with the broader efforts of other international organizations taking part in the Aid for Trade initiative, and the current WTO negotiations on trade facilitation which take full account of the special and differential treatment needs of the less developed country members will hopefully provide the trading environment that is free from the barriers to trade that have inhibited these countries from integration into the global supply chain and the benefits thereof.

32) Fourth Global Review of Aid for Trade, 8-10 July 2013, held in Geneva, WTO headquarters. Website information on: http://www.wto.org/english/tratop_e/devel_e/a4t_e/global_review13_e.htm. 


\section{REFERENCES}

Anderson, James E. and Eric van Wincoop (2004), 'Trade Costs', Journal of Economic Literature 42(3).

Bagai, Shweta, Richard Newfarmer, and John S. Wilson (2004), 'Trade Facilitation: Using WTO Disciplines to Promote Development', World Bank Trade Note 15, 10 May 2004.

Finger, J. Michael and John S. Wilson (2006), 'Implementing a WTO Agreement on Trade Facilitation: What Makes Sense?', World Bank Policy Research Paper 3971.

Grainger, Andrew (2011), 'Trade Facilitation: A Conceptual Review', Journal of World Trade 45 (1), 39-62.

Hoekman, Bernard and Alessandro Nicita (2008), 'Trade Policy, Trade Costs, and Developing Country Trade', World Bank Policy Research Paper 4797.

Hoekman, Bernard and Alessandro Nicita (2010), 'Assessing the Doha Round: Market Access, Transaction Costs and Aid for Trade Facilitation', Journal of International Trade \& Economic Development 19(1).

Lee, Hyo-young and Chong-Sup Kim (2012), 'The Impact of Trade Facilitation on the Extensive and Intensive Margins of Trade: An Application for Developing Countries', Journal of East Asian Economic Integration 16(1).

Limao, Nuno and Anthony J. Venables (1999), 'Infrastructure, Geographical Disadvantage, and Transport Costs', World Bank Policy Research Paper 2257.

Messerlin, Patrick A. and Jamel Zarrouk (2000), 'Trade Facilitation: Technical Regulations and Customs Procedures', World Economy 23(4).

Nakagawa, Junji (2012), 'The WTO at a Critical Juncture', Paper presented at the Asia International Economic Law Network (AIELN) III Seoul Conference, July 2013. 
OECD, The Economic Impact of Trade Facilitation (2005), OECD Trade Policy Working Paper No. 21, TD/TC/WP(2005)/12/FINAL (12 Oct. 2005).

UNCTAD, World Investment Report 2013, Global Value Chains: Investment and Trade for Development.

Wilson, John S., Catherine L. Mann, and Tsunehiro Otsuki (2003), 'Trade Facilitation and Economic Development: A New Approach to Quantifying the Impact', World Bank Economic Review 17(3).

Wilson, John S., Catherine L. Mann, and Tsunehiro Otsuki (2005), 'Assessing the Benefits of Trade Facilitation: A Global Perspective', World Economy 28(6).

Wilson, John S. and Tsunehiro Otsuki (2007), 'Regional Integration in South East Asia: What Role for Trade Facilitation?', World Bank Policy Research Paper 4423.

World Bank (2010), Connecting to Compete: Trade Logistics in the Global Economy, The Logistics Performance Index and Its Indicators, Washington, D.C.

WTO, World Trade Report 2011, The WTO and Preferential Trade Agreements: From Co-existence to Coherence. 